\title{
Developing a Model of Next Generation Knowledge Management
}

\author{
Kenneth A. Grant \\ Ryerson University, Toronto, \\ Ontario, Canada, \\ \& American University in Bulgaria, \\ Elieff Centre, Sofia, Bulgaria \\ Candace T. Grant \\ Ryerson University, \\ Toronto, Ontario, Canada
}

kagrant@ryerson.ca

Abstract

Knowledge Management exploded into visibility as a management topic in the mid-1990s with a significant impact in the IT applications area. It has had high visibility for the last decade and, in recent years, has come under some critical scrutiny - - questioning the success of many of the attempts to manage knowledge, especially those with an IT focus, as well as some suggestion that it was merely the latest management fad, now facing inevitable decline. As a counter to this, some experts have proposed the emergence of a "next" generation that both resolves the limitations of the previous generation and offers additional understanding that could lead to more successful ventures. A view of the evolution of Knowledge and Knowledge Management through four stages is presented and a composite model for Next Generation Knowledge Management (NGKM) is proposed, derived from the theories presented by several prominent authors.

Key Words: Next Generation Knowledge Management, Knowledge Models, IT, Communicating Meaning, Philosophy

\section{Introduction}

This paper presents a view of the evolution of the use of Knowledge and Knowledge Management (KM) through four stages, and suggests a composite model for Next Generation Knowledge Management (NGKM), derived from the theories presented by several prominent authors. The four stages are:

- Knowledge as the domain of philosophers and scientists

- Precursors to knowledge as a management issue

Material published as part of this publication, either on-line or in print, is copyrighted by the Informing Science Institute. Permission to make digital or paper copy of part or all of these works for personal or classroom use is granted without fee provided that the copies are not made or distributed for profit or commercial advantage AND that copies 1) bear this notice in full and 2) give the full citation on the first page. It is permissible to abstract these works so long as credit is given. To copy in all other cases or to republish or to post on a server or to redistribute to lists requires specific permission and payment of a fee. Contact Publisher@InformingScience.org to request redistribution permission.
- The emergence of Knowledge Management as a discipline and First Generation Knowledge Management

- Next Generation Knowledge Management

The paper concludes with a discussion of the model's practical implications and makes suggestions for testing the model in practice. 
It has significance both for the future management of knowledge-related functions and the role of IT in helping to create and share knowledge.

\section{Stage I: Knowledge as the Domain of Philosophers and Scientists}

For more than two millennia, trying to understand the nature of knowledge has been the key of philosophers and scientists. Figure 1 provides a simple pictorial representation of the philosophical thinking about knowledge (at least from the Western perspective), demonstrating the roots of the philosophy of knowledge that have led to the much more recent concept of Knowledge Management. Seven key groupings can be seen. The discussions on knowledge start with the work of Plato and Aristotle. Plato, in the Theaetetus, one of his Socratic dialogues (Plato, 369BC) tries to answer the question "What is knowledge?" He proposes three key concepts: "Knowledge is perception"; "Knowledge is true belief"; and "Knowledge is true belief with an account".

Although some re-visitation of the ideas of Plato and Aristotle was evident in the Scholasticism of the later Middle Ages it was not until the beginning of the $17^{\text {th }}$ Century that the next wave of thinking about knowledge emerged.

The Rationalists, following in the footsteps of Plato, argued that the fundamental characteristics of the physical world are known independently of the senses, while the Empiricists, in supporting the views of Aristotle, argued for more practical evidence.

By the early $20^{\text {th }}$ century, epistemologists' arguments had developed with a recognition that it was much more difficult to be certain about anything, exemplified by Wittgenstein's thought evolution on the role of language.

This debate happened largely in the University and in the laboratory. Meanwhile, for much of this period, there was a parallel process of knowledge creation and transfer that was happening in the workplace-- that of the apprenticeship within a skilled craft. In evidence in many early societies, this method of acquiring both cognitive and practical skills was based on the transfer of skills from master to apprentice and the three stage evolution from apprentice to journeyman to master. 


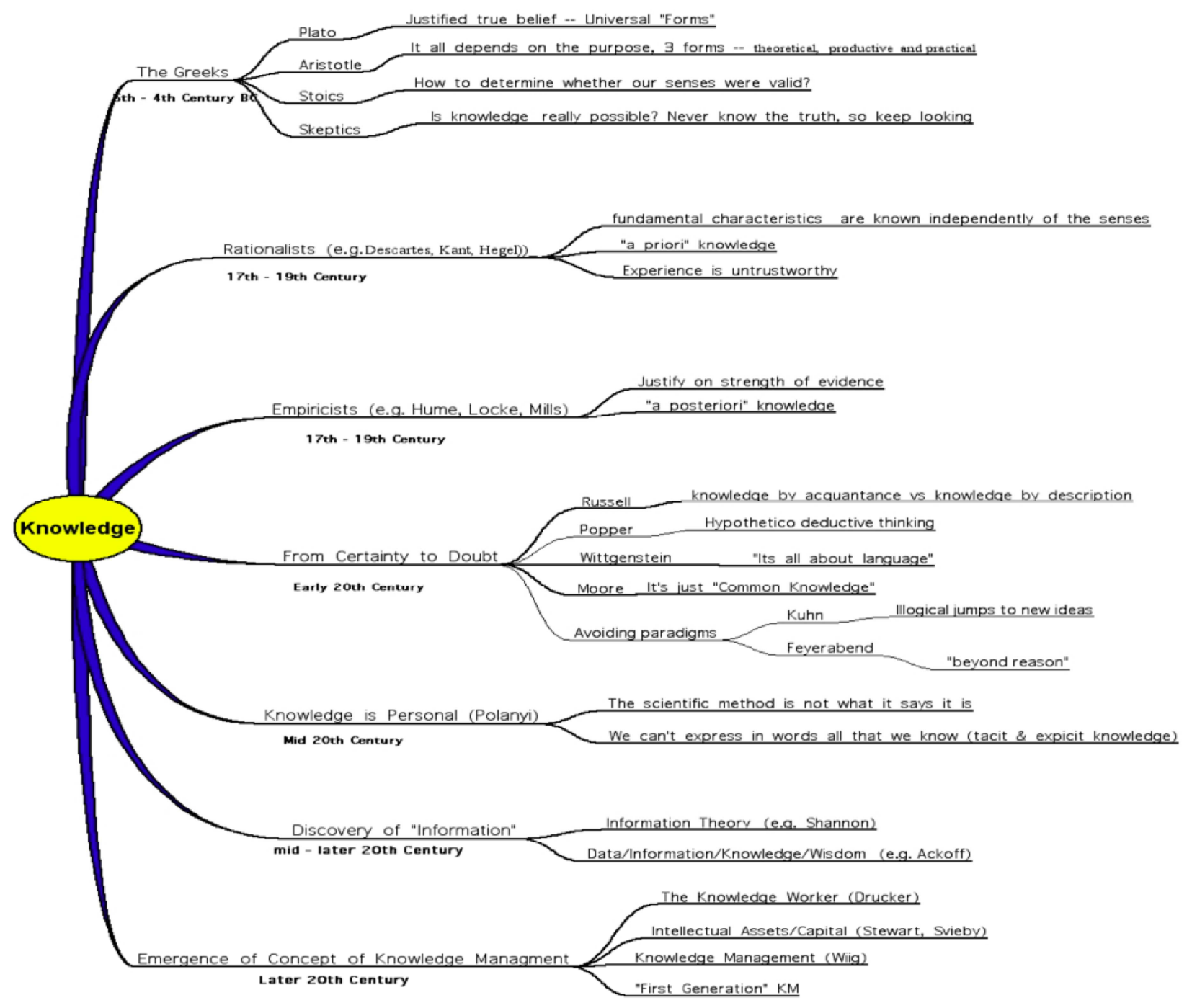

Figure 1: A Timeline of Thinking About Knowledge

\section{Stage II: Precursors to Knowledge as a Management Issue}

By the mid $20^{\text {th }}$ century, a number of activities, both theoretical and practical, had demonstrated an emergence of knowledge as a subject of interest to management.

\section{Michael Polanyi \& "Personal Knowledge"}

Of special note in this evolution is the work of Michael Polanyi. In common with many other philosophers in the early to mid $20^{\text {th }}$ century he saw the weaknesses inherent in the "objective" scientific method and moved towards a more post-modernist view. In his major work, "Personal Knowledge" (Polanyi, 1958), he develops his theory of Personal Knowledge, based on the belief that all knowledge is to some degree tacit, and sets the foundation for much of the later theoretical work done in the KM field. In many ways, Polanyi can be seen as a bridge between the philoso- 
phical works on knowledge and the beginnings of an approach to the explicit role and use of knowledge in business communities.

Polanyi speaks much more of "knowing" rather than of "knowledge" and roots much of his argument on the role of language in communicating knowledge. While suggesting that language is a vital tool we can use to share knowledge, he also emphasizes that we can often know how to do things without either knowing or being able to articulate to others why what we do works (the "tacit dimension"). He distinguishes skills and how we learn them from knowledge, suggesting "The aim of a skilful performance is achieved by the observance of a set of rules which are not known to the person following them."

\section{The Information Era}

A far more visible element in this transition was the impact of information and communications technology in business. Indeed, it was this transition that introduced us to the concept of "information" as distinct from data and knowledge - - until then, something that had appeared unnecessary. We first see "information" used in a business context in Shannon's work at Bell Labs on information transmission (Shannon, 1948), which focuses on the successful transmission of a correctly understandable message, despite the impact of noise or entropy. Since then, the terms "data" and "information" have been used in many forms -- they are often used interchangeably but they cannot be considered synonyms and sometimes their uses are contradictory!

The growth of the use of the term in business is closely linked to the increasing use of computers. At first, computers were seen as tools for "data processing", then by the mid-1970s it became management information systems (MIS) (Beer, 1972), with "Chief Information Officers" appearing by the early 1980s (Synnott \& Gruber, 1981). We also saw the development of the DIKW (Data/Information/ Knowledge/Wisdom) hierarchy, usually credited to Ackoff (Ackoff, 1989).

Cybernetic concepts also emerged in the mid-1900's gaining more practitioner interest as the power of computers grew. One proponent of cybernetics, Stafford Beer, argued for biological analogies between individual thinking and corporate thinking -- for example in the "Brain of the Firm" (Beer, 1972), largely based on the concept of "corporate knowledge". By the 1970s this work was also being presented as General Systems Theory (GST) by authors such as von Bertalanffy, Mead, Churchman and Checkland. From this we saw the emergence of the concepts of Artificial Intelligence and Expert Systems.

\section{Stage III: The Emergence of Knowledge Management as a Discipline and First Generation KM}

As Karl Wiig (1999) has suggested:

The business direction we call knowledge management (KM) has emerged over the last decades as a result of many intellectual, societal and business forces. Some of its roots extend back for millennia, both in the West and the East, while others, particularly those associated with Cognitive and Information sciences, are quite recent.

Figure 2 provides a simple illustration showing the results of a search for the term "knowledge management" on EBSCO and Proquest (Carried out on June $5^{\text {th }}, 2007$ ), indicating that, as suggested by a number of authors, 1996 is a reasonable start date for the first generation of KM (FGKM).

Visual inspection of the results suggests that the EBSCO results come mainly from academic journals, while the Proquest results draw from a wider range of sources. Each plot demonstrates a period of rapid growth, plateauing in the last few years (with a noticeable drop in the Proquest 
citations in 2001/2 that coincides with the well-reported fall-off in attention to IT following the dot.com meltdown and the passing of the Y2K fear.

A more detailed examination of the KM literature suggests that, by 1996-1998, there was an explosion of work that was beginning to coalesce into a single field that might be described as "knowledge management".

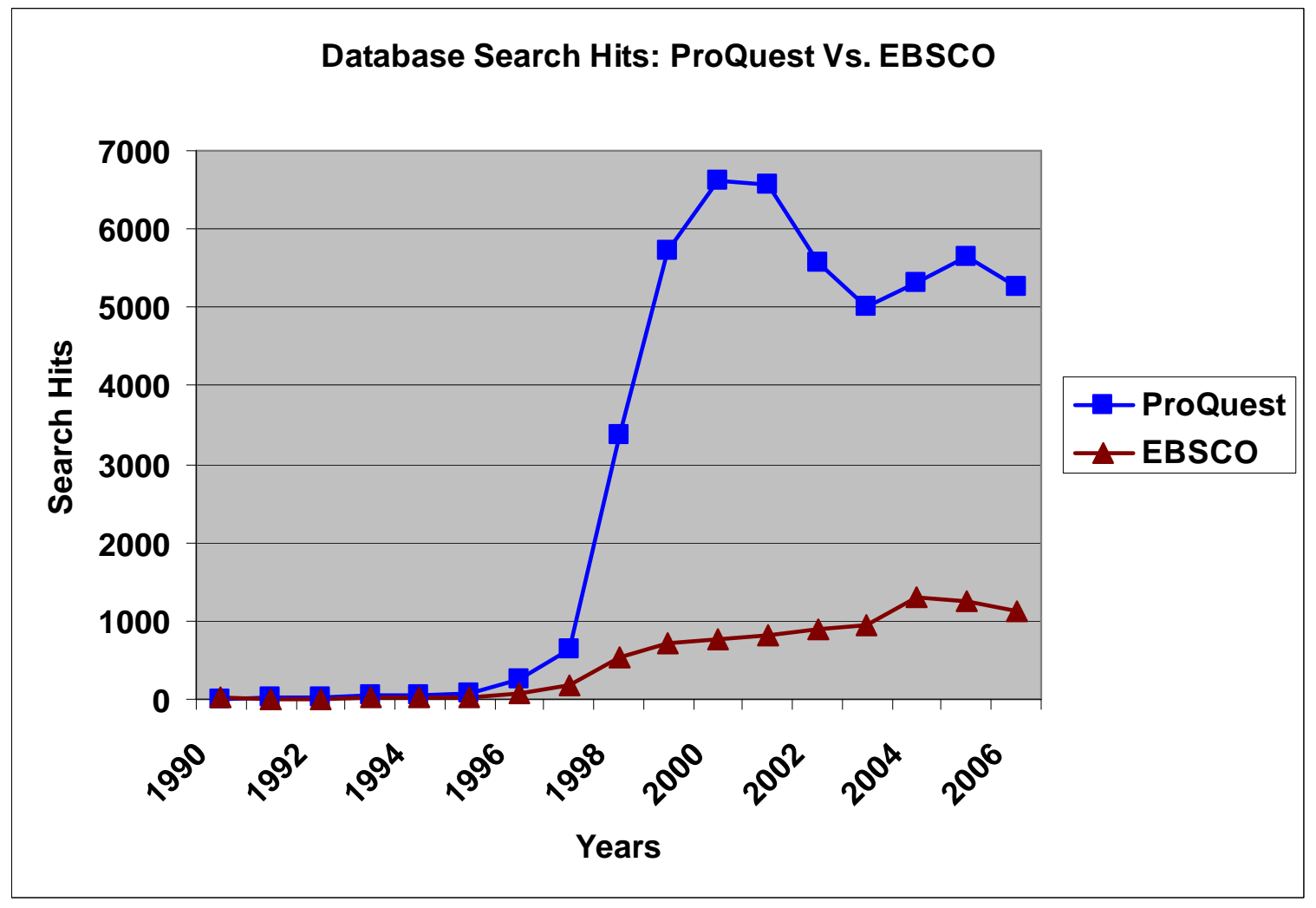

Figure 2: Database Search Results of a Search for "Knowledge Management"

From this examination, five themes are evident:

1. The management and exploitation of "intellectual capital"

2. Social views of knowledge: organizational learning and communities of practice

3. Knowledge work and knowledge models and processes

4. The widespread use of it to capture, codify and share knowledge

5. The need to manage knowledge activities at both the strategic and operational levels.

Each of these is discussed below. 


\section{Theme 1: The Management and Exploitation of "Intellectual Capital"}

The late 1980s and early 1990s saw pioneering efforts that led to the concept of KM as a distinct discipline emerging by the mid-1990s. Karl-Erik Sveiby's early work in Sweden on "Intellectual Capital" (for example Sveiby \& Risling, 1986) is seen by many as the beginning of the knowledge management movement. Presenting the concept of the invisible balance sheet and the value of "know-how", he argues this intellectual capital can be identified, measured and managed. This inspired a number of Swedish initiatives, amongst which Lief Edvinsson's work at Skandia is prominent, where he was likely the first CKO, appointed in 1991.

In North America, wider popularization of the concept likely started with Thomas Stewart's writings in Fortune magazine (Stewart, 1991, 1994). The first of these, titled "Brainpower," suggests that:

"Knowledge has become the primary ingredient of what we make, do, buy, and sell. As a result, managing it finding and growing intellectual capital, storing it, selling it, sharing it has become the most important economic task of individuals, businesses, and nations."

\section{Theme 2: Social Views of Knowledge: Organizational Learning and Communities of Practice}

Evolving from the world of general systems theory referenced earlier, and the work of Schon (Schön, 1973) and Levitt and March (Levitt \& March, 1988), this theme was popularized by Senge in his book "the Fifth Discipline" (Senge, 1990). Moving beyond the well-established concepts of individual training and development, organizational learning was seen as adaptive learning, responding to environmental change and proactive learning to pursue corporate goals. Suggesting key topics of systems thinking, personal mastery, mental models, building shared vision and team learning, Senge described learning organizations as:

...organizations where people continually expand their capacity to create the results they truly desire, where new and expansive patterns of thinking are nurtured, where collective aspiration is set free, and where people are continually learning to see the whole together.

Brown \& Duguid (1991) discuss the importance of informal communities of practice in success for learning organizations, linking working learning and innovation. At the same time, Wenger described the nature of such communities in another case study (Lave \& Wenger, 1991) and demonstrated the existence of communities of practice in an analysis of apprenticeship systems.

\section{Theme 3: Knowledge Work and Knowledge Models and Processes}

\section{Knowledge work and the knowledge worker}

The early 1990s also saw the beginnings of the examination of the "knowledge worker" as a specific topic of interest. Peter Drucker is often credited with making the distinction of knowledgeintensive work. He proposed a new type of worker - the "knowledge worker", with some special characteristics - one key element of which is that a knowledge worker is a unique individual and not the replaceable unit of production envisaged for labour in the industrial economy. (Drucker, 1992). 


\section{Knowledge models}

The most significant single paper published in this period was Ikijiro Nonaka's "The KnowledgeCreating Company" (Nonaka 1991). Published at a time that the Japanese companies were considered to have superior business models to those of North American companies, in this work Nonaka "corporatized" the concept of "personal tacit" knowledge, as originally proposed by Polanyi (Polanyi, 1958) and proposed a spiral model for knowledge creation and transfer which was later formalized as the SECI Model (Socialization, Externalization, Internalization, Combination). This model, along with its fundamental assumption that tacit knowledge can be transferred and can also be converted to explicit knowledge, all set in a corporate context, is likely the most widely adopted knowledge management concept in the first generation. (Nonaka, 1994; Nonaka \& Takeuchi, 1995)

Somewhat later, drawing on the work of Japanese philosopher Kitaro Nishida, Nonaka also suggested the need to create an appropriate environment in which knowledge can be created and transferred, describing this as a "Ba" -- a shared space for emerging relationships, that might be physical, virtual, or mental, providing a platform for advancing individual and/or collective knowledge. (Nonaka \& Konno, 1998)

The importance of Nonaka's work is evidenced by its dominance as, by far, the most referenced material in the KM field (K. A. Grant, 2006; Serenko \& Bontis, 2004) and by the number of practitioner projects implementing elements of the model. Further, while a variety of other knowledge classification systems have been proposed, variations on Nonaka's interpretation of Polanyi's original tacit/explicit knowledge concept dominate in the literature - both academic and practitioner.

\section{Knowledge processes}

The late 1980s and early 1990s saw a widespread focus on business process reengineering, peaking at the time that Hammer \& Champy published "Reengineering the Corporation" (Hammer \& Champy, 1993), along with an increased recognition of the importance of business processes as a primary means of adding value. A number of authors, such as Davenport \& Prusak in "Working Knowledge" (Davenport \& Prusak, 1998) discussed the issues relevant to applying process models to knowledge work, differentiating between processes that apply knowledge and processes intended to create knowledge.

\section{Theme 4: The Widespread use of IT to Capture, Codify and Share Knowledge}

The discussion that concludes the previous section and the earlier review of the role of cybernetics and expert systems suggests a long-term association between knowledge activities and information systems. In addition, by the mid-1990s the evolution of the personal computer and personal computer applications such as word processing, spreadsheets and personal databases had reached a reasonably mature state. Telecommunications and private network applications were pervasive in many organizations, using communications applications such as email and voice mail and newer "groupware" tools such as LotusNotes were being offered to the market.

The mid-1990s also saw the Internet explosion, with its rapid growth in both Internet sites and users, especially in North America. This provided a growing body of users, both individual and corporate, with access to information sites, communication tools such as email, and an increasing number of group and community tools, including "Intranets". More recently this has continued with the emergence of "Web 2.0" phenomena with close links to the knowledge field, such as wikis, blogs and social networking tools. (Though these have yet to be adopted by the KM community to any significant degree.) 
Significant claims have been made for the contribution of IT to successful KM. Frappaolo and Capshaw suggest that KM systems can intermediate (connect people), externalize (explicit knowledge to users), internalize (extract and filter external knowledge) and improve cognition (connecting knowledge to process, to help decision making) (Frappaolo \& Capshaw, 1999).

To give an idea of the scale of IT-related KM, the Gartner Group (Eid, 2005) suggested a 2004 market size of almost $\$ 6$ billion, just for content management and collaboration software, predicting that this might grow to $\$ 9$ billion by 2009 .

\section{Theme 5: The Need to Manage Knowledge Activities at both the Strategic and Operational Levels}

Starting in the early 1990s, many authors and practitioners were arguing that there was a need for explicit focus on the management of knowledge-related functions and processes. In response to these challenges, a significant number of organizations have created a key management role -- the Chief Knowledge Officer or CKO (Earl \& Scott, 1999).

One of the first to look at KM as a business practice was Karl Wiig, founder of the Knowledge Research Institute, whose trilogy of books (Wiig, 1993, 1994, 1995) set out frameworks for knowledge creation and dissemination and for its direction and management.

KM was also seen as a key element of the RBV (Resource-based view) strategy school, which gained significant support in the 1990's as an alternative (or extension to) to the market positioning school that dominated much of strategic planning in the previous decade (Porter, 1985). A firm's knowledge was seen as a key element of the RBV and as part of strategic planning (R. M. Grant, 1996).

This strategic view also held that knowledge forms a basis for competitive advantage. Zack (Zack, 1999) demonstrated a link between a firm's strategy and its use of knowledge and proposes the use of a Strategic Knowledge Map to examine an organization's competitive position.

Earl identified seven different strategies for KM (Earl, 2001), while a much simpler approach is suggested by Hansen et al, who suggest that the key strategic choice is between a codification approach or a personalization approach (Hansen, Nohria, \& Tierney, 1999).

\section{Common Criticisms of FGKM}

It is clear from the work done by many of the recognised authorities in the field - both academic and practitioner -- that the field of KM has seen significant evolution over the very short period it has been a centre of management attention.

During this period, while there has been much debate about the nature of knowledge, and the role of KM, there has been relatively limited critical assessment of its commonly held views and practices. Criticisms of KM tended to cluster around four main categories:

\section{The "Fad" argument}

Some authors have suggested that KM is indeed just another management fad. For example, Wilson describes it as "in large part, a management fad, promulgated mainly by certain consultancy companies, and the probability is that it will fade away like previous fads." (Wilson, 2002)

Ponzi and Koenig (2002) examine the degree to which KM can be seen as a fad (something that emerges very quickly, is adopted with great zeal and declines just as fast) or a fashion (a fad that briefly shows signs of maturity before declining). They provide empirical evidence, based on bibliographic counts, that suggests management fads generally peak in some 5 years, using the examples of quality circles, total quality management and business process reengineering. Apply- 
ing the same approach to the case of knowledge management, in the period 1991 to 2001, they argue that "knowledge management has weathered the five-year mark and perhaps is becoming an addition to the management practice". Ironically, as Exhibit II shows earlier, there was some decline in 2002/3, however the citation data has yet to demonstrate the rapid decline typical of a fad or fashion.

\section{An overfocus on IT}

In a survey of knowledge management papers from 1990-2000, Swan \& Scarborough (2002) found that more than $40 \%$ were written by and for computer or IS/IT professionals, suggesting that the IT community "has become an important professional patron of KM." They further suggest that, although a common rationale for KM calls for a variety of management practices, the patronage of KM by specific professional communities, especially that of IT, has paradoxical effects -- promoting its use and success, but also separating it into areas of narrow focus, thus limiting its effectiveness.

As Swan \& Scarborough highlighted, single community focus tends to be sub-optimal. Binney (2001) criticizes this approach and argues for a KM spectrum, incorporating a number of perspectives, including the role of enabling technologies. In contrast, Gartner Research (Harris, 2006) suggests that while "strictly speaking, KM does not require the use of software" they "believe that $\mathrm{KM}$ technology is necessary to a good KM program." In one study of $28 \mathrm{KM}$-related KM projects, less than $50 \%$ were deemed to be successes, with very few successes involving more than the sharing of explicit knowledge.(K. A. Grant \& Qureshi, 2006)

\section{The questionable validity of the models that underlie KM practice}

Many alternative models and classification systems have been proposed for KM, with a major focus evident in the literature on Nonaka's SECI cycle and the conversion of tacit to explicit knowledge, likely driven by the over-focus on IT discussed above. Several critics have pointed out this is, at minimum, an oversimplification. For example, Styhre suggests that "in the knowledge management literature, there is little patience with an organizational resource that cannot be reduced into a number of categories and skills" (Styhre, 2003) and criticizes the codification or knowledge representation approach.

Some others go further, suggesting that knowledge and management are contradictory concepts (e.g. Schultze \& Stabell, 2004) particularly the belief that, in order to manage tacit knowledge, it must be made explicit. Marren (2003) attacks the whole concept of KM, the existence of "corporate" knowledge and the focus on knowledge as an end in itself, without link to the action or business advantage. Wilson also debunks the concept of KM in a wide-ranging review of reference sources, suggesting that "in many cases, 'knowledge management' is being used simply as a synonym for information management." He goes on to attack Nonaka \& Takeuchi's SECI model by arguing that their model misrepresents the concept of tacit knowing developed by Polanyi (1958). Many of these arguments have an epistemological basis, ranging from the critical or post-modernist view, to those that are presented more simply as the difference between information and knowledge.

\section{The usefulness and validity of the knowledge itself}

Underlying all this is an even more fundamental question -- is the knowledge that is being created, captured, shared or recorded actually useful and relevant knowledge? These concerns are especially true of explicit knowledge, frequently captured in IT systems.

Much has been written about the challenge of capturing useful knowledge. Concerns range from the quality of the knowledge being captured and presented to the challenges in getting individuals 
within the organization to actually contribute to the knowledge base. Often the repositories created are not seen as the best source for useful knowledge. For example, despite the existence of expert directories, informal networks are often the best way of finding the right person.

Further, in the knowledge management literature, there is relatively little focus on getting the right knowledge and making sure of the validity of that knowledge and its relevance for the situations in which it is being used. For example is what is being captured "best" practice or just "any" practice? Surprisingly, the KM literature is largely silent on this issue, and there is limited attention paid to it in the more theoretical work. This is almost paradoxical, since much of the philosophers' debate has centred on the very meaning of "justified true belief".

\section{Stage IV: Key Views of the "Next” Generation of KM}

This criticism coalesced in the early 2000's around a view that we were at the end of a stage or generation and that, in order to respond to these criticisms, a new generation of thinking and action was needed.

Several authors have developed their views of what this "next" generation might be and the work of four key proponents (Mark McElroy, David Snowden, Karl-Eric Sveiby and Karl Wiig) is reviewed below.

\section{McElroy's "Second Generation Knowledge Management"}

McElroy(2002, 2003), drawing on work he started in the late 90s, argues that First Generation Knowledge Management (FGKM) was largely based on a narrow, technology-centric brand of thinking and that a new Second Generation Knowledge Management (SGKM) is emerging. His SGKM has a focus on demand not supply, and a recognition of a more complex environment, where IT has much less of a role and where knowledge is seen to exist at several levels within an organization.

He characterizes FGKM as having an underlying assumption that valuable knowledge exists within the organization and that "The hallmark of first generation KM is its overwhelming emphasis on the capture, codification and distribution of existing knowledge through an organization" (McElroy, 2002)-- in other words by converting tacit to explicit knowledge that can easily be shared, often through information systems. He describes this as "supply-side" KM.

In defining SGKM as a management discipline that focuses on organizational learning with business innovation and competitive advantage in mind, he presents a Knowledge Life Cycle -- a "framework of models" in which "many different and competing views on how knowledge is produced and integrated in organizations can be organized and positioned relative to one another." This is seen as "demand-side" KM, the belief that knowledge processes are, at the core, social systems, leads to the claim that these processes are largely self-organizing, but within discernable patterns with a given organization. Also underlying McElroy's SGKM view is the concept of Complex Adaptive Systems (CAS) from complexity theory.

This leads to set of prescriptions for SGKM in practice. First, he proposes a KM strategy framework (see Figure 3). He argues that this can be used as the framework for all KM strategy and that management's only ways to impact actual knowledge performance are by two forms of intervention - policy or program. 


\begin{tabular}{c|c|c|}
\multicolumn{1}{c}{} & \multicolumn{1}{c}{$\begin{array}{l}\text { Knowledge } \\
\text { Production }\end{array}$} & \multicolumn{1}{c}{$\begin{array}{c}\text { Knowledge } \\
\text { Integration }\end{array}$} \\
\cline { 2 - 3 } $\begin{array}{c}\text { Social } \\
\text { Interventions }\end{array}$ & $\begin{array}{c}\text { Demand-side } \\
\text { Social KM }\end{array}$ & $\begin{array}{c}\text { Supply-side } \\
\text { Social KM }\end{array}$ \\
\cline { 2 - 3 } $\begin{array}{c}\text { Technology } \\
\text { Interventions }\end{array}$ & $\begin{array}{c}\text { Demand-side } \\
\text { Technology } \\
\text { KM }\end{array}$ & $\begin{array}{c}\text { Supply-side } \\
\text { Technology } \\
\text { KM }\end{array}$ \\
\cline { 2 - 3 } & &
\end{tabular}

Figure 3: A Knowledge Management Strategy Framework (McElroy, 2003)

\section{Snowden's Third Generation Knowledge Management}

Snowden suggests that we are moving towards a third generation (Snowden, 2002). His three generations are:

- Generation 1: Late 80s to mid-90s, largely information and ICT focused;

- Generation 2: Mid-90s to early $21^{\text {st }}$ century, focused on tacit-explicit knowledge conversion, triggered by the SECI model of Nonaka;

- Generation 3: Just beginning now, based on complexity theory.

He describes this as a progression from Content to Narrative to Context, claiming that this new generation is not a simple evolution, but a change in paradigm - "as large a change as the shift from Newtonian to modern physics, it challenges the conceptual underpinnings of process management and scientific management in general."

For him, "Knowledge Management is the creation of shared context. The interplay of context and content and the level of abstraction are key to the notion of knowledge sharing." We are dealing with both ordered and unordered (chaotic) situations and that creating spaces in which this can take place are critical. His arguments have some similarity with, but go beyond, Nonaka's "ba" construct. As with McElroy, he sees Complex Adaptive Systems Theory as the key to understanding the role of KM. In Snowden's view, this distinction between content and context is key. Shared context is needed for understanding. KM is "creating information from data by the provision of shared context" and "Real" knowledge management is heuristic, not prescriptive (he suggests the analogy of chef versus recipe).

Fundamentally, his view is that there are strong ecological/anthropological roots to KM. He identifies three key heuristics to the new way to manage knowledge:

- Knowledge can only be volunteered, it cannot be conscripted.

- We can always know more than we can tell and we will always tell more than we can write down.

- We only know what we need to know when we need to know it.

Snowden has used the word "Cynefin," a Welsh word meaning "a place" to label the sensemaking framework he has developed to distinguish between formal and informal communities. The framework is shown in Figure 3. (Note: it is presented in various forms in Snowden's work.) With dimensions of low to high abstraction and a need for learning vs. teaching, he defines four "open spaces" or domains of knowledge: 
- Known: Where the formal organization can usually handle knowledge activities

- Knowable: Where groups of "professionals" can create and share knowledge

- Complex: where voluntary and informal networks can provide common understanding

- Chaos: Where new situations dominate and there is a need to impose pattern on chaos to make it comprehensible and manageable.

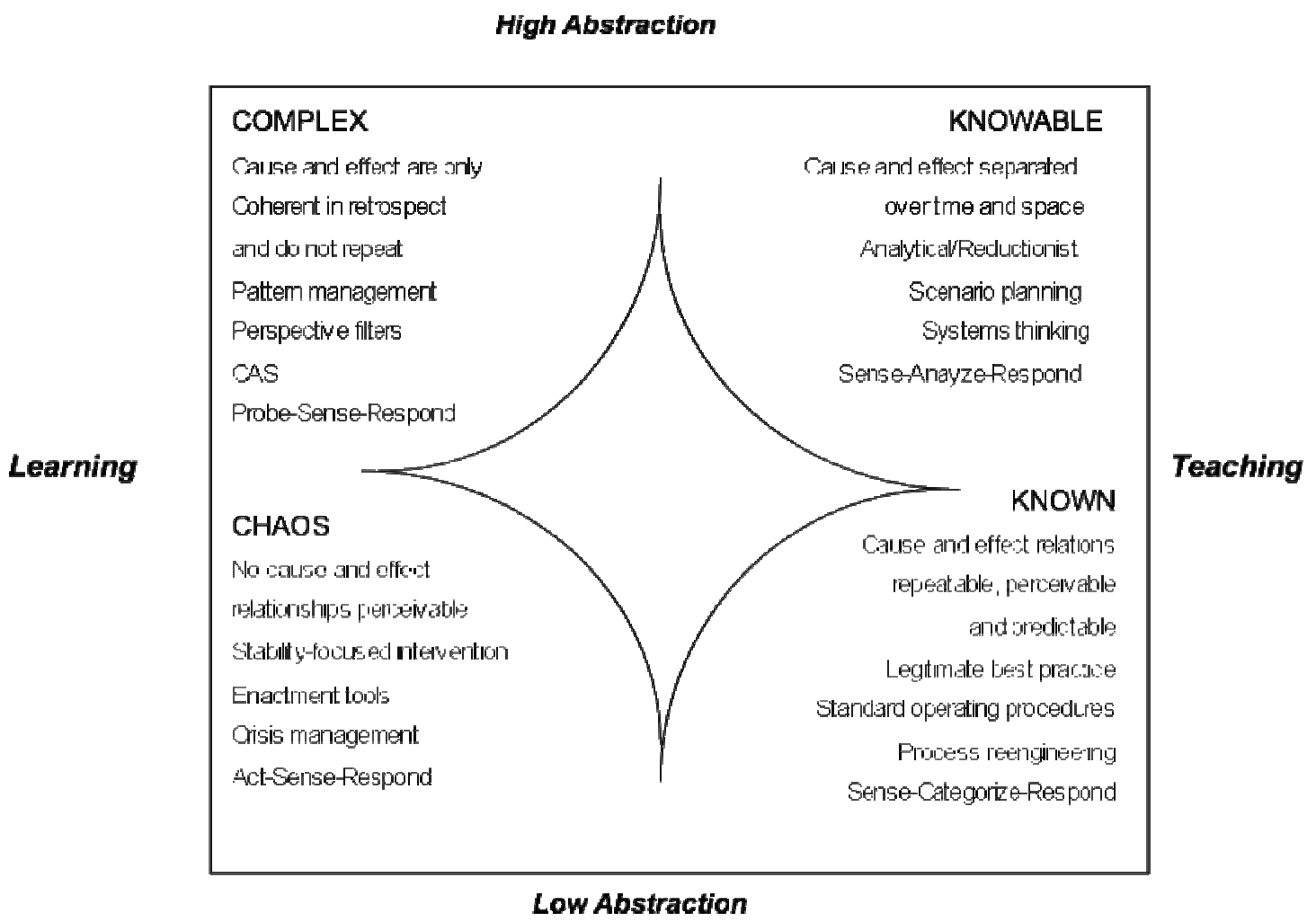

Figure 3: Snowden's Cynefin Domains

\section{Sveiby's Focus on People and Intangible Assets}

While he does not explicitly use the term of NGKM, Sveiby also addresses the need for a new approach to KM. In an interview, he describes the "American" interpretation of KM based on "the management of information, making it available in the whole organization, generating, capturing and harvesting, making the knowledge in people's heads so that it can be stored and retrieved." This has been a huge disappointment to the promises from the IT companies..." In contrast, he describes his own focus for a "people oriented track that is only right now beginning to emerge".

Sveiby's knowledge strategy is to enable people to "use their competence to create value in two directions: by transferring and converting knowledge externally or internally to the organization." He defines three families of intangible resources which interact to create this value, as shown in Figure 4 (Sveiby, 2001). 


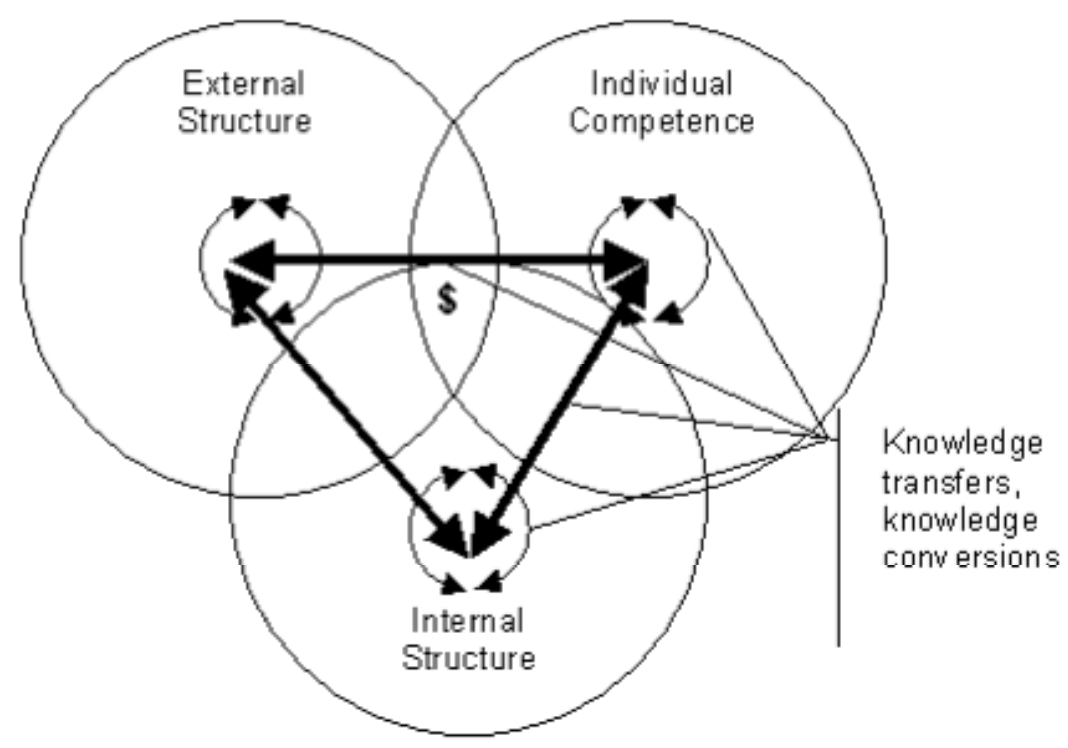

Figure 4: Sveiby's View of the Firm from a Knowledge-Based Perspective

\section{Wiig's Next Generation Knowledge Management}

Wiig's new generation is driven by a demand-pull of management and operating philosophies and practice developments with an IC focus, drawing on positive practical experiences with KM and a supply push of new science and technology developments.

He believes that enterprise effectiveness comes from the individual actions of its employees and the collective actions of its management. Thus, NGKM emphasizes creating the right corporate environment in which people can make personal contributions to the overall enterprise, with a much deeper understanding both of how individuals acquire, use and share knowledge and how corporations can plan and organize to use this knowledge effectively in pursuit of corporate goals.

Combining four areas of focus -- People, Intellectual Assets, Technology can lead to a comprehensive and strategic perspective on KM. (See Figure 5.)

For Wiig, NGKM organizations are characterised by:

- Broad and proactive philosophy and management;

- Knowledge focused strategies and practices;

- An IS stewardship mentality, systematic;

- Self sustaining and self-renewing KM practices, a systems perspective;

- Vigilant application of state-of-the-art KM practices and Infrastructure. 


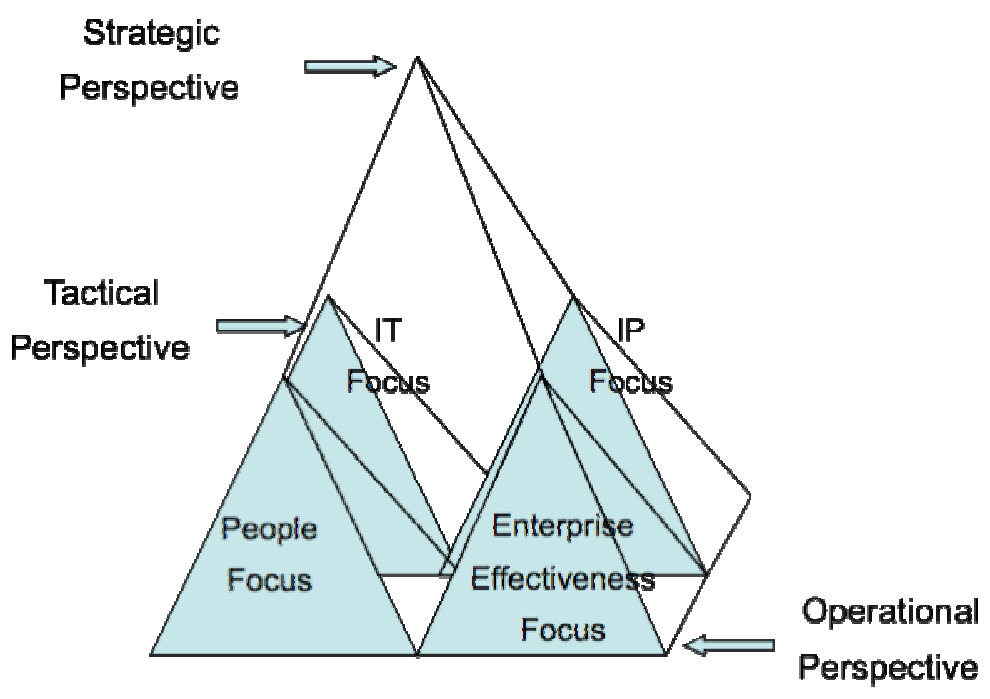

Figure 5: Operational, Tactical and Strategic Perspectives (Wiig, 2004)

\section{Developing a Composite Model of "Next Generation" Knowledge Management}

In reviewing these descriptions of the "Next Generation", several common propositions or themes emerge. While they may have been proposed/described in First Generation KM, the difference here is that they are being proposed in combination, rather than as a single focus. These are summarized below and the level of support from each of the key authors reviewed earlier is demonstrated in Table 1. The support is described as "strong" if there is significant direct evidence from the author's work describing the theme and its importance. It is described as moderate, if the theme is directly mentioned by the author but not as a critical element of that author's theory.

\section{Theme 1: The Need for a Strategic Focus}

General Concept: Firms must have specific strategies for knowledge management to realize the benefits.

As McElroy suggests, the Knowledge Life Cycle is the key to successful SGKM and the act of Knowledge Management is something "that seeks to have impact on knowledge processing."(McElroy, 2002). Sveiby has a slightly different perspective arguing that "A knowledgebased strategy formulation should thus start with the primary intangible resource: the competence of people" and that the key is to leverage knowledge transfers/conversions to create new value. This is also key to Wiig's approach (Wiig, 2004).

\section{Theme 2: The Role of IT}

General Concept: The IT focus that has largely dominated the first generation, while it has had some success, has not brought the results hoped for by many.

As McElroy has said, in FGKM "the goal of KM has been to capture, codify and distribute organizational knowledge (usually in centrally managed computer systems)" and that this has "provoked a discernable backlash" in the marketplace that has damaged the credibility of KM (McElroy, 2000). 
Table 1: Key Themes of Next Generation Knowledge Management

\begin{tabular}{|c|c|c|c|c|c|}
\hline $\begin{array}{c}\text { THE KEY THEMES OF “NEXT } \\
\text { GENERATION” KM }\end{array}$ & $\begin{array}{l}\text { McElroy } \\
2 G K M\end{array}$ & $\begin{array}{l}\text { Snowdon } \\
\text { 3GKM }\end{array}$ & $\begin{array}{l}\text { Sveiby } \\
\text { Assets }\end{array}$ & $\begin{array}{c}\text { Wiig } \\
N G K M\end{array}$ & $\begin{array}{c}\text { Other } \\
\text { Authors }\end{array}$ \\
\hline $\begin{array}{l}\text { TOPIC: STRATEGIC FOCUS } \\
\text { Firms must have specific strategies for knowl- } \\
\text { edge management to realize the benefits }\end{array}$ & Strong & & Moderate & Strong & \\
\hline $\begin{array}{l}\text { TOPIC: THE ROLE OF IT } \\
\text { The IT focus that has largely dominated the } \\
\text { first generation, while it has had some suc- } \\
\text { cess, has not brought the results hoped for by } \\
\text { many. }\end{array}$ & Strong & Strong & & Moderate & $\begin{array}{l}\text { Ponzi } \\
\text { Miles }\end{array}$ \\
\hline $\begin{array}{l}\text { TOPIC: THE USEFULNESS OF KM MOD- } \\
\text { ELS } \\
\text { Models and taxonomies of knowledge while } \\
\text { useful in helping to understand the nature of } \\
\text { knowledge in organizations do not show how } \\
\text { to make effective use of knowledge. }\end{array}$ & Moderate & Strong & & Moderate & \\
\hline $\begin{array}{l}\text { TOPIC: USING EXISTING KNOWLEDGE } \\
\text { AND CREATING NEW KNOWLEDGE } \\
\text { While knowledge activities include the effec- } \\
\text { tive use of existing knowledge, it is more } \\
\text { important to improve how new knowledge is } \\
\text { acquired, particularly in terms of business } \\
\text { innovation. }\end{array}$ & Strong & Strong & Strong & Strong & $\begin{array}{l}\text { Miles } \\
\text { St Onge }\end{array}$ \\
\hline $\begin{array}{l}\text { TOPIC: THE COMPLEXITY OF KNOWL- } \\
\text { EDGE MANAGEMENT } \\
\text { Newer thinking recognizes greater complexity } \\
\text { in the knowledge challenges facing organiza- } \\
\text { tions, and includes consideration of knowl- } \\
\text { edge management in the context of complex } \\
\text { adaptive systems }\end{array}$ & Strong & Strong & & & Ponzi \\
\hline $\begin{array}{l}\text { TOPIC: THE PERSONAL AND SOCIAL } \\
\text { NATURE OF KNOWLEDGE } \\
\text { Much of this complexity comes from the } \\
\text { highly personal nature of knowledge and the } \\
\text { difficulty of institutionalizing this knowledge } \\
\text { without taking into account a variety of group } \\
\text { or social issues. }\end{array}$ & Strong & Strong & Strong & Strong & $\begin{array}{l}\text { Allee } \\
\text { Miles } \\
\text { St Onge }\end{array}$ \\
\hline $\begin{array}{l}\text { TOPIC: INTELLECTUAL ASSET MAN- } \\
\text { AGEMENT } \\
\text { The primary reason that firms have market } \\
\text { value above book value is the recognition of } \\
\text { IP and IC and these need to be explicitly man- } \\
\text { aged }\end{array}$ & Moderate & & Strong & Strong & St Onge \\
\hline ADDITIONAL DIMENSIONS & $\begin{array}{l}\text { Formal } \\
\text { Mgt. Inter- } \\
\text { vention } \\
\text { Structure } \\
\text { \& Ops }\end{array}$ & $\begin{array}{l}\text { Chaos } \\
\text { "Un- } \\
\text { order" }\end{array}$ & & & \\
\hline
\end{tabular}

Snowden describes the problem as "Most knowledge management in the post-1995 period has been to all intents and purposes content management." While recognising the overfocus, Wiig is more moderate and sees IT as a critical but not the key element (Wigg, 2004). 


\section{Theme 3: The Usefulness of KM Models}

General Concept: Early models and taxonomies of knowledge (such as the tacit/explicit dimension) have been useful in helping to understand the nature of knowledge in organizations but do not, in themselves, show how to make effective use of knowledge.

McElroy claims that FGKM is very transactional emphasizing the capture and codification of existing knowledge, which is not the key focus of NGKM. The issue is "demand-side" not "supplyside" KM (McElroy, 2002). Snowden points out that, "The deficiencies of the SECI model in practice are becoming evident" and that there is a body of tacit knowledge that cannot be made explicit" (Snowden, 2000). It should be noted, however, that each of these author does, in fact, propose new models aiming to make up for the deficiencies of their predecessors.

\section{Theme 4: Using Existing Knowledge and Creating New Knowledge}

General Concept: While knowledge activities include the effective use of existing knowledge, it is more important to improve how new knowledge is acquired, particularly in terms of business innovation.

McElroy's Knowledge Life Cycle provides a formal set of procedures to produce and integrate knowledge in the organization and he suggests that "accelerating the production of new knowledge is a far more valuable proposition" than codifying existing knowledge. KLCs exist at multiple levels, including the corporate level and represent a "management discipline" (McElroy, 2002). This is also supported by Sveiby, although he is a little more focused on the effective use of existing knowledge (Sveiby, 2001) and Wiig, who suggests a hierarchy of processes, from operational through tactical to strategic.(Wigg, 2004).

\section{Theme 5: The Complexity of Knowledge Management}

General Concept: A new wave of thinking about the use of knowledge in organizations is emerging, which recognizes greater complexity in the knowledge challenges facing organizations, and includes consideration of knowledge management in the context of complex adaptive systems.

McElroy claims that NGKM is "firmly rooted in complexity theory." Such concepts as nested knowledge domains and the role of individual knowledge agents combining to form collective or shared organizational knowledge are key examples (McElroy, 2002). In Snowden's "third age" the knowledge environment can be complicated, complex and chaotic and an understanding of the relevant "knowledge space" is critical to success (Snowden, 2002)

\section{Theme 6: The Personal, Social and Collective Nature of Knowledge}

General Concept: Much of this complexity comes from the highly personal nature of knowledge and the difficulty of institutionalizing this knowledge without taking into account a variety of group or social issues. Organizations can have collective knowledge.

As McElroy claims, drawing on Senge's earlier work "organizations not just individuals, actually learn" and that the tension "between what individuals know and knowledge held collectively by groups of individuals" is a stimulant for innovation and creativity (McElroy, 2002). Snowden further says that "much knowledge is held collectively within communities and cannot be represented as the aggregation of individual knowledge" (Snowden, 2000). 


\section{Theme 7: Intellectual Asset Management}

General Concept: The primary reason that firms have market value above book value is the recognition of IP and IC and these need to be explicitly managed

In essence, the least changed of the FGKM concepts, Intellectual Capital is still seen as key, taken into account with the other six themes of NGKM.

While the four views described in detail in Exhibit $\mathrm{X}$ represent some of the most fully developed views of NGKM, other authors make similar suggestions that a new approach to KM is emerging (or is needed).

Examples include the work of St Onge and Armstrong, who see the evolution of the "Conductive Organization" (Saint-Onge \& Armstrong., 2004) and Allee, who focuses on "Value Networks." (Allee, 2003) as well as Miles, Snow, and Miles (2000) look at future business models and integrate many of the themes found in the discussion around the links between knowledge management and innovation.

\section{Practical Applications of the Model}

This paper has traced the evolution of knowledge and Knowledge Management from their beginnings to the present day. Contrasting views of a Next Generation of Knowledge Management are described and a composite model derived from these views. Such a model has several potential uses.

First, it demonstrates, by reviewing and combining the thoughts of a number of leading authors in the field, that there are strong arguments to be made that the First Generation of KM has had wide ranging impact but has also failed to deliver on many of the promised benefits. It offers a perspective that goes beyond the single theme approaches so common in FGKM, especially for those working in the IT field.

Second, for the practitioner, it provides an accessible framework to address the next generation thinking of a number of key authors and allows for the evaluation of current strategies and practices in KM to help identify weaknesses and opportunities for improvement.

\section{Conclusions}

The field of knowledge management has seen significant evolution since it's emergence in the mid-1990's, with significant investments made with very varied results. It has also seen some decline in management and research focus and some accusations that it is just another "management fad". Many of these failures and accusations can be attributed directly to the weaknesses of "First Generation" KM, with its tendency to work in single discipline silos and an overwhelming focus on the use of Information Technology -- often in conjunction with a belief that tacit knowledge can be convert to explicit knowledge and stored in IT systems. Some of the problem may also be associated with a frequent disregard for the evolution of thought around "knowledge" than has been built over the last two millennia.

Proponents of "Next Generation" KM have proposed a more holistic approach to resolve the problems of the first generation and common themes can be identified across their views. This paper has proposed a composite model that incorporates the view of key proponents of the "Next" generation. While these new models offer promise, they still suffer from the same weaknesses that have troubled many of the other models developed during the first generation -- a lack of testing and validation in the field. Thus, the next step in this research activity will be to attempt to validate the existence of this new generation in the workplace, using the composite model as the research framework. 


\section{Testing the Model in Practice}

As discussed above, this is still just a theoretical model till it can be tested in practice. Since the model is claimed to describe a next generation of KM and it is based on the current work in the field by key researchers/practitioners, it should be evident in practice -- organizations should exist that are using these concepts in practice and achieving demonstrable success.

A number of possibilities exist to carry out such a study. It could be argued that this generation would be most likely observed in organizations for which effective use of knowledge is seen as key to the success of their business. These are often described as knowledge-intensive firms (KIF). In particular, one such class of KIFs is that of Professional Services Firms. These deal only with knowledge-related services and can demonstrate a range of approaches with predictable differences, depending on the types of service offered.

Thus, the next step in this research is an ongoing series of case studies in professional services firms (consultants, accountants, lawyers, engineers) to determine whether current practice in these firms provides evidence to support an evolution from first to second generation knowledge management. Further these case studies will allow the validation of the composite model, as well as of elements of the individual models proposed by the various authors.

\section{References}

Ackoff, R. L. (1989). From data to wisdom. Journal of Applied Systems Analysis, 16.

Allee, V. (2003). The future of knowledge: Increasing prosperity through value networks. Burlington, MA: Butterworth-Heinemann.

Beer, S. (1972). Brain of the firm: The managerial cybernetics of organization: The Penguin Press.

Binney, D. (2001). The knowledge management spectrum -- Understanding the KM landscape. Journal of Knowledge Management, 5(1), 33-42.

Brown, J. S., \& Duguid, P. (1991). Organizational learning and communities-of-practice: Toward a unified view of working, learning, and innovation. Organization science, 2(1), 40-57.

Davenport, T. H., \& Prusak, L. (1998). Working knowledge: How organizations manage what they know. Cambridge, MA: Harvard Business School Press.

Drucker, P. ( 1992). Managing for the future. Oxford: Butterworth Heinemann.

Earl, M. J. (2001). Knowledge management strategies: Toward a taxonomy. Journal of Management Information Systems, 18(1), 215-233.

Earl, M. J., \& Scott, I. A. . (1999). What is a Chief Knowledge Officer? Sloan Management Review, Winter.

Eid, T. (2005). Market trends: Content, communications and collaboration technologies in the highperformance workplace. The Gartner Group.

Frappaolo, C., \& Capshaw, S. (1999). Knowledge management software: Capturing the essence of knowhow and innovation. Information Management Journal, 33(3), 44-48.

Grant, K. A. (2006). Tacit knowledge revisited - is there something still to be learned from Polanyi? Proceedings Of The ICICKM 2006 International Conference on Intellectual Capital, Knowledge Management and Organisational Learning, 19-20 October 2006, Pontificia Universidad Católica de Chile, Santiago, Chile

Grant, K. A., \& Qureshi, U. A. (2006). Knowledge management systems -- Why so many failures? Proceedings of Innovations in Information Technology, Dubai, pp. 1-5

Grant, R. M. (1996). Prospering in dynamically-competitive environments: Organizational capability as knowledge integration. Organization Science, 7(4), 375-387. 
Hammer, M., \& Champy, J. (1993). Reengineering the corporation: A manifesto for business revolution. Harper Business.

Hansen, M. T., Nohria, N., \& Tierney, T. (1999). What's your strategy for managing knowledge? Harvard Business Review, 77(2).

Harris, K. (2006). Knowledge management enables the high performance workplace. Gartner Inc.

Lave, J., \& Wenger, E. (1991). Situated learning: Legitimate peripheral participation. Cambridge University Press

Levitt, B., \& March, J. G. (1988). Organizational learning. Annual Review of Sociology, 14, 319-340.

Marren, P. (2003). Where did all the knowledge go? Journal of Busines Strategy, 24(3), 5-7.

McElroy, M. W. (2000). Integrating complexity theory, knowledge management and organizational learning. Journal of Knowledge Management, 4(3), 195-203.

McElroy, M. W. (2002). Second generation knowledge management. Retrieved from http://www.macroinnovation.com/images/McElroy_On_2ndGenKM.pdf

McElroy, M. W. (2003). The new knowledge management. Burlington, MA: Butterworth-Heinemann.

Miles, R. E., Snow, C. C., \& Miles, G. (2000). TheFuture.org. Long Range Planning, 33.

Nonaka, I. (1991). The knowledge creating company. Harvard Business Review, 69(6)

Nonaka, I. (1994). A dynamic theory of organizational knowledge creation. Organizational Science, 5(1).

Nonaka, I., \& Konno, N. (1998). The concept of "Ba': Building foundation for knowledge creation. California Management Review, 40(3).

Nonaka, I., \& Takeuchi, H. (1995). The knowledge creating company: How Japanese companies create the dynamics of innovation. Oxford: Oxford University Press.

Plato. (369BC). Theaetetus.

Polanyi, M. (1958). Personal knowledge: Towards a post-critical philosophy. Chicago: University of Chicago Press.

Ponzi, L. J., \& Koenig, M. (2002). Knowledge management: Another management fad? Information Research, 8(1).

Porter, M. (1985). Competitive advantage. New York: Free Press.

Saint-Onge, H., \& Armstrong, C. (2004). The conductive organization: Building beyond sustainability, : Elsevier Butterworh-Heinemannn.

Schön, D. A. (1973). Beyond the stable state. Public and private learning in a changing society. Harmondsworth: Penguin.

Schultze, U., \& Stabell, C. (2004). Knowing what you don't know? Discourses and contradictions in knowing management research. The Journal Of Management Studies, 41(4).

Senge, P. M. (1990). The fifth discipline: The art and practice of the learning organization. New York: Doubleday.

Serenko, A., \& Bontis, N. (2004). Meta-review of knowledge management and intellectual capital literature. Knowledge and Process Management, 11(3), 185.

Snowden, D. (2000). New wine in old wineskins: From organic to complex knowledge through the use of story. Emergence, 24(4), 50-64.

Snowden, D. J. (2002). Complex acts of knowing, paradox and descriptive self-awareness. Journal of Knowledge Management, Spring.

Stewart, T. A. (1991). Brainpower. Fortune, 123(11), 44-50. 
Stewart, T. A. (1994). Your company's most valuable asset: Intellectual capital. Fortune

Styhre, A. (2003). Understanding knowledge management: Critical and postmodern perspectives. Copenhagen: Copenhagen Business School Press.

Sveiby, K.-E. (2001). A knowledge-based theory of the firm to guide strategy formulation. Journal of Intellectual Capital, 2(4).

Sveiby, K.-E., \& Risling, A. (1986). öretagetKunskapsf("The knowhow company") Sweden.

Swan, J., \& Scarborough, H. (2002). The paradox of "knowledge management". Informatik Informatique, 2002(1), 10-13.

Synnott, W. R., \& Gruber, W. H. (1981). Information resource management: Opportunities and strategies for the 1980s. New York: John Wiley \& Sons.

Wiig, K. (1993). Knowledge management foundations: Thinking about thinking - How organizations create, represent and use knowledge Schema Press.

Wiig, K. (1994). The central management focus for intelligent-acting organizations. Schema Press.

Wiig, K. (1995). Knowledge Management Methods: Practical Approaches to Managing Knowledge. Schema Press.

Wigg, K. (1999). Knowledge management: An emerging discipline rooted in a long history. In C. Despres \& D. Chauvel (Eds.), Knowledge horizons: The present and the promise of knowledge management. New York, NY: Butterworth-Heinemann.

Wigg, K. (2004). People-focussed knowledge management. New York, NY: Butterworth-Heinemann.

Wilson, T. D. (2002). The nonsense of 'knowledge management'. Information Research, 8(1).

Zack, M. (1999). Developing a knowledge strategy California Management Review, Spring.

\section{Biographies}

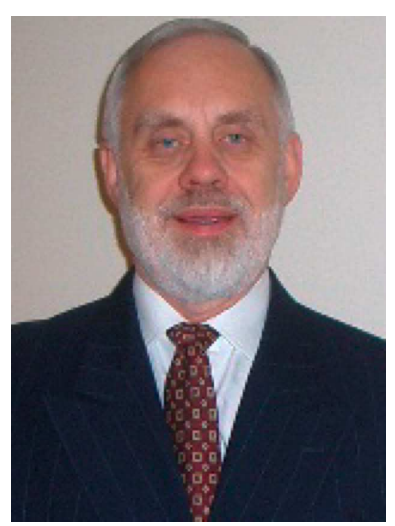

Kenneth A. Grant, BA, MBA, DBA (ABD), G.Dip. Management Consulting. Ken is a professor in Ryerson University's Ted Rogers School of Management and a management consultant with over 30 years of consulting experience. He is also a visiting professor at the American University in Bulgaria. He teaches and researches in the areas of Business and IT Strategy, Knowledge Management, Process and Performance Improvement and Electronic Commerce.

He has held senior partner/vice president positions in major consulting firms, including A.T. Kearney/ EDS and KPMG and is a frequent author and speaker on business and IT topics.

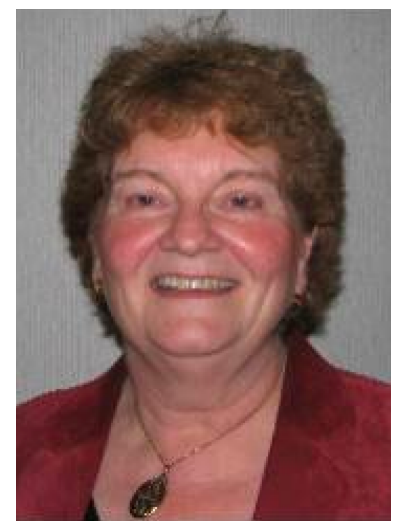

Candace Grant, BA, EMBA, G.Dip. Knowledge Management. Candace is a professor in Ryerson University's Ted Rogers School of Management and a management consultant with over 25 years in the information technology sector, focusing on software development, process improvement, quality assurance and knowledge transfer.

Candace has extensive experience in course design, development and delivery in both the private and the public sector. Her research interests include the ethical use of knowledge in today's knowledge-based economy and the role of knowledge in project-based environments. 